Article

\title{
The Role of Humic Acid, PP Beads, and pH with Water Backwashing in a Hybrid Water Treatment of Multichannel Alumina Microfiltration and PP Beads
}

\author{
Sungju Hwang, Yooju Lee and Jin Yong Park *(D) \\ Department of Environmental Sciences \& Biotechnology, Hallym University, Chunchon 24252, Korea; \\ 6402aa@naver.com (S.H.); zztm1320@naver.com (Y.L.) \\ * Correspondence: jypark@hallym.ac.kr
}

Received: 31 October 2019; Accepted: 23 December 2019; Published: 25 December 2019

check for updates

\begin{abstract}
Photooxidation oxidizes most organic compounds by mineralizing them to small inorganic molecules. In this study, the effects of dissolved organic matter (DOM), $\mathrm{pH}$, and polypropylene (PP) beads concentration on membrane fouling were investigated in a hybrid water treatment process consisting of seven-channel alumina microfiltration (pore size $1.0 \mu \mathrm{m}$ ) and pure PP beads water backwashing with UV irradiation for photooxidation. The synthetic feed was prepared with humic acid and kaolin and flowed inside the microfiltration (MF) membrane. The permeate contacted the PP beads fluidized in the gap of the membrane and module with outside UV irradiation. Membrane fouling resistance $\left(R_{f}\right)$ increased dramatically with an increase in the concentration of humic acid (HA) from $6 \mathrm{mg} / \mathrm{L}$ to $8 \mathrm{mg} / \mathrm{L}$. The treatment efficiency of DOM increased dramatically, from $14.3 \%$ to $49.7 \%$, with an increase in the concentration of HA. The $R_{f}$ decreased with an increase of PP beads concentration. However, maximum permeate volume $\left(V_{T}\right)$ was acquired at $5 \mathrm{~g} / \mathrm{L}$ of PP beads. The maximal treatment efficiency of DOM was $51.3 \%$ at $40 \mathrm{~g} / \mathrm{L}$ of PP beads. The $R_{f}$ increased with an increase in the $\mathrm{pH}$ of feed, and the maximum $V_{T}$ was acquired at a $\mathrm{pH}$ of 5 . The maximal treatment efficiency of DOM was $52.5 \%$ at $\mathrm{pH} 9$.
\end{abstract}

Keywords: microfiltration; photooxidation; adsorption; polypropylene bead; hybrid treatment; water treatment; alumina

\section{Introduction}

The membrane separation process for separation and purification has developed dramatically during the past few decades. It can separate and concentrate all pollutants simultaneously in water by the retention of its microspores without secondary pollution and phase change. Additionally, its equipment is compact, easy to operate, and capable of continuous operation at room temperature with the advantage of low energy consumption [1]. However, membrane fouling due to the adsorption-precipitation of organic and inorganic compounds onto membranes leads to a decrease in the permeate flux, which increases membrane cleaning costs and reduces membrane life. Techniques for controlling membrane fouling remain inadequate, which is the major obstacle in the successful implementation of membrane separation technology, although considerable progress has been made in membrane fouling [2,3]. Natural organic matter (NOM) is a primary component of fouling in low-pressure membrane filtration. Various preventive measures to interfere with NOM fouling have been developed and extensively tested, such as coagulation, oxidation, ion exchange, carbon adsorption, and mineral oxide adsorption [4]. In this study, periodic water backwashing was performed to prevent the membrane fouling.

Recently, the hybrid technology of membrane separation and photooxidation by UV irradiation has effectively solved the above-mentioned membrane fouling problem [5]. Hybrid technology not only 
maintains the advantages of each technology, but also produces synergistic effects that overcome the limits of only one technology of membrane separation and photooxidation. In addition, pollutants such as NOM can be oxidized by UV irradiation, and organic species are rejected partially by controlling the residence time in the reacting system. In other words, the membrane is also a selective barrier for the separated molecules. Finally, hybrid technology increases photooxidation efficiency and acquires excellent effluent quality. The effect of UV-irradiation on the nano-hybrid PES-NanoZnO membrane in terms of flux and rejection efficiency has also been discussed in [6]. In addition, a comparison of the efficiency of surface water treatment in hybrid systems by coupling various advanced oxidation processes and ultrafiltration (UF) was presented by [7]. In this study, a hybrid process of ceramic membrane and pure PP beads with UV irradiation was applied for advanced water treatment.

The ceramic membranes, used in this study, have numerous advantages, which are mechanical, thermal, and chemical resistance, as well as a long lifetime. These are economically competitive as compared with polymeric membranes, because of an almost permanent lifetime [8]. Nowadays, ceramic membranes have been widely applied in water or wastewater throughout the world $[9,10]$. The influence of the soluble algal organic matter (AOM) characteristic on the fouling of a seven-channel tubular ceramic (MF) membrane has been investigated at lab scale by [11]. The influence of the interaction between aquatic humic substances and the algal organic AOM derived from Microcystis aeruginosa on the fouling of a ceramic MF membrane has been studied by [12].

Photooxidation has the characteristics of high efficiency, low energy consumption, and a wide range of application, by mineralizing organic compounds to small inorganic molecules and oxidization of most them, especially nonbiodegradable organic contaminants. In addition, it is an excellent technology for water pollution control. For this reason, the photooxidation technology applied in this study has been applied broadly [13-18]. In addition, degradation of humic acid (HA), which was contained in a synthetic solution used in this study, via the photoelectrocatalysis (PEC) process and the corresponding disinfection byproduct formation potential (DBPFP) were investigated; the PEC process was found to be effective in reducing dissolved organic carbon concentration [19].

In our research group, on the one hand, the results for the effect of operating conditions on a hybrid water treatment process of various ceramic membranes and titanium dioxide $\left(\mathrm{TiO}_{2}\right)$ photocatalyst-coated polypropylene (PP) were published in "Desalination and Water Treatment" [20] and "Membr. J." [21]. On the other hand, the roles of adsorption and photooxidation in a hybrid water treatment process of tubular carbon fiber UF and pure PP beads with UV irradiation and water backwashing were reported by our group in "Desalination and Water Treatment" [22].

In this study, the roles of humic acid, pure PP beads concentration, and $\mathrm{pH}$ were investigated on membrane fouling in a hybrid water treatment process of seven-channel alumina MF membranes and pure PP beads with water backwashing and UV irradiation. This research involved the unique application of pure PP beads to investigate the effect of HA, pure PP beads, and $\mathrm{pH}$ on the hybrid process of multichannel MF membrane as compared with our previous results [20-22]. Periodic water backwashing was performed for $10 \mathrm{~s}$ per $10 \mathrm{~min}$ of filtration to reduce membrane fouling. A hybrid module was composed of the MF membranes and the PP beads, which were fluidized between the gap of carbon fiber membrane and the acryl module case. The results of humic acid, pure PP beads concentration, and $\mathrm{pH}$ effects were compared with those of the previous study [22,23] for the hybrid process of the tubular carbon fiber UF (pore size $0.05 \mu \mathrm{m}$ ) membranes and pure PP beads with water backwashing, to investigate the effects on membrane fouling and treatment efficiency depending on membrane module types and materials.

\section{Materials and Methods}

The seven-channel alumina MF (HC10) membranes, used in the study, were manufactured in Dongseo Industry (Seoul, Korea), with pore sizes of $0.10 \mu \mathrm{m}$. The specifications of the HC10 alumina membrane are listed in Table 1. In this study, 4 to $6 \mathrm{~mm}$ size polypropylene (PP) beads were applied and the average weight was $39.9 \mathrm{mg}$. A quantity of HA and kaolin was dissolved in distilled water, instead 
of natural organic matter and fine inorganic particles in a natural water source. In this experiment, it was utilized as synthetic feed water. For photooxidation, two UV lamps (F8T5BLB, Sankyo, Tokyo, Japan) irradiated UV with $352 \mathrm{~nm}$ from outside of the acryl module.

Table 1. Specifications of multichannel ceramic microfiltration (MF) membrane used in this study.

\begin{tabular}{cc}
\hline Membrane Model & HC10 \\
\hline Pore size $(\mu \mathrm{m})$ & 0.1 \\
No. of channels & 7 \\
Outer diameter $(\mathrm{mm})$ & 20 \\
Inner diameter $(\mathrm{mm})$ & 4 \\
Length $(\mathrm{mm})$ & 245 \\
Surface area $\left(\mathrm{cm}^{2}\right)$ & 215 \\
Material & $\alpha$-alumina \\
Company & Dongseo Industry (Korea) \\
\hline
\end{tabular}

To remove the turbidity and DOM, the hybrid module was packed with pure PP beads in the space between the module inside and outside of the alumina membrane. Additionally, a 100 mesh $(0.150 \mathrm{~mm})$ sieve, which was much smaller than 4 to $6 \mathrm{~mm}$ particle size of the PP beads used here, was installed at the outlet of the hybrid module to contain the PP beads in the module.

The hybrid water treatment process (6) of multichannel MF membrane and the pure PP beads (7), which were used in the previous study [24], are shown in Figure 1 and Scheme 1. A periodic water backwashing using permeated water was performed for the multichannel MF membrane. The hybrid module (6) was supplied with PP beads fluidizing between the gap of carbon fiber membrane and the acryl module case. Then, $10 \mathrm{~L}$ of the synthetic water with HA and kaolin was contained in the feed tank (1). To maintain a constant viscosity of water, the temperature of the feed water was constantly maintained using a temperature circulator (3) (Model 1146, VWR, Atlanta, GA, USA). To maintain the homogeneous condition of the feed water, the synthetic feed water was continuously mixed by a stirrer (4), and it flowed into the inside of the MF membrane by a pump (2) (Procon, Standex Co., Smyna, TN, USA). A flowmeter (5) (NP-127, Tokyo Keiso, Tokyo, Japan) measured the feed flow rate. Controlling valves (9) of both the bypass pipe of the pump (2) and the concentrate pipe maintained constant flow rate and pressure of the feed water that flowed into the hybrid module. An electric balance (11) (Ohaus, Newark, NJ, USA.) measured the permeate flux treated by both the MF membrane and the PP beads. During the permeate, flux had not been measured and the permeate water flowed into the backwashing tank (13). To maintain a constant concentration of the feed water during operation, it was recycled to the feed tank (1) after the treated water was over a certain level in the backwashing tank (13). Physical washing was performed by a brush inside the tubular membrane after each operation, and the permeate flux was measured to calculate the resistances of irreversible and reversible membrane fouling. 


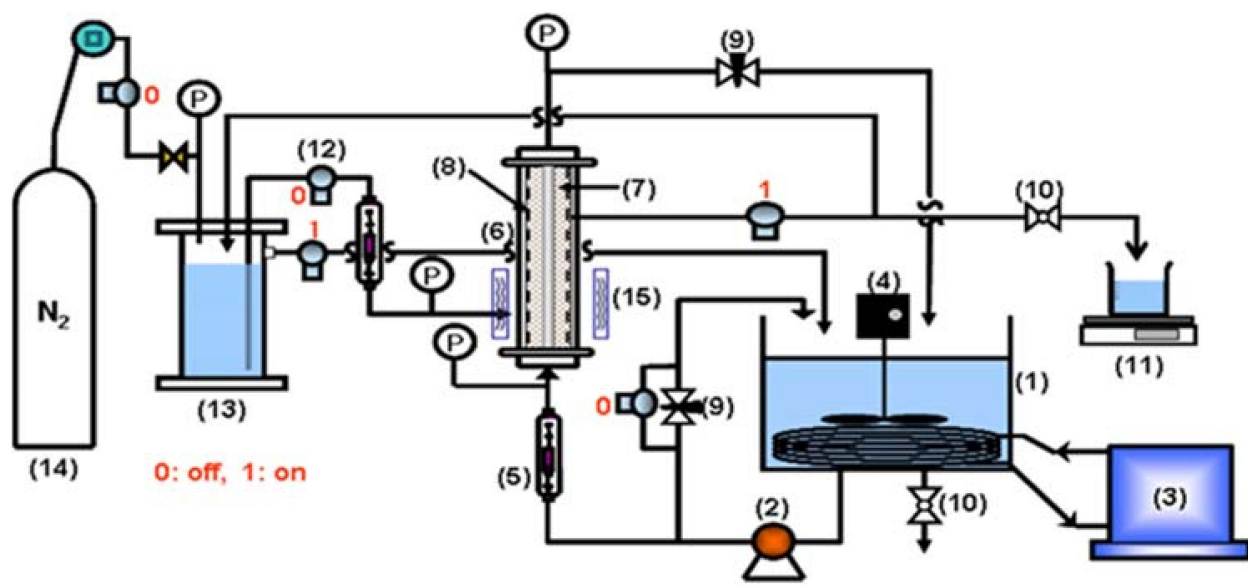
(1) Feed tank
(2) Feed pump
(3) Cooling system
(4) Stirrer
(5) Flow meter
(6) Membrane module
(7) PP beads
(8) 100 mesh sieve
(9) Needle valve (control)
(10) Ball valve
(11) Electric balance
(13) Backwashing tank
(14) Nitrogen vessel
(12) Solenoid valve
(15) UV lamp

Figure 1. Apparatus of hybrid water treatment process of tubular carbon fiber ultrafiltration (UF)and microfiltration (MF) membrane and PP beads with periodic water backwashing [24].

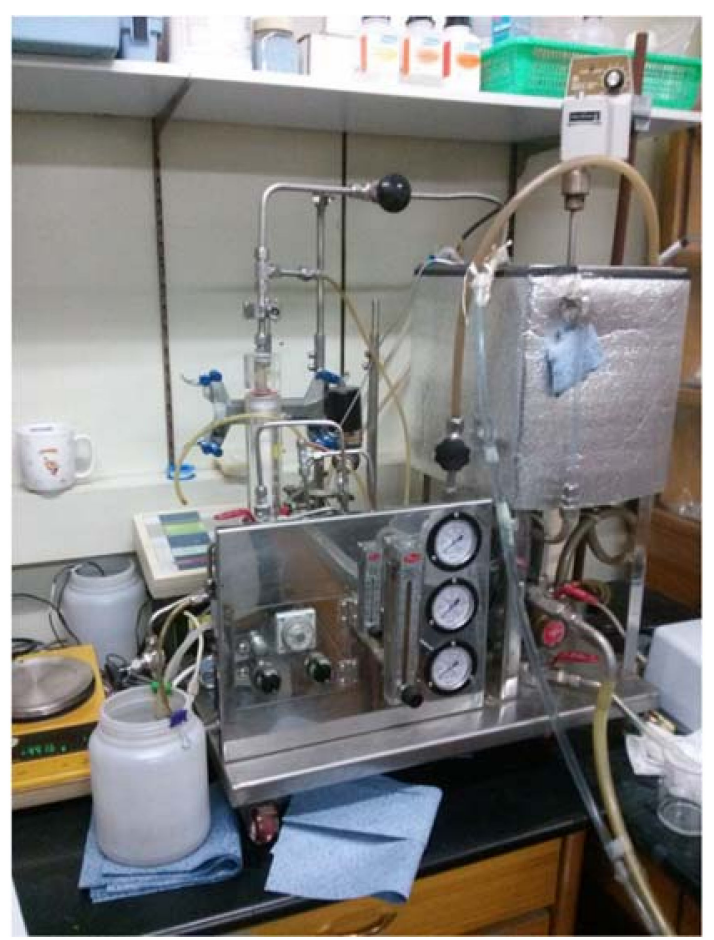

(a)

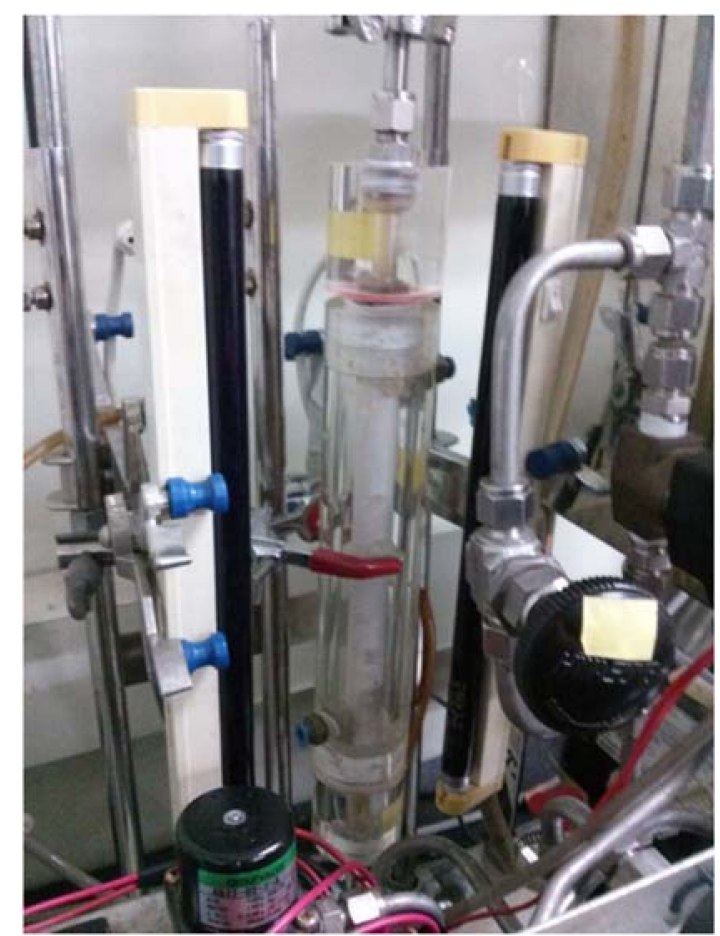

(b)

Scheme 1. Hybrid water treatment process system of tubular carbon fiber UF/MF membrane and PP beads with periodic water backwashing: (a) Total hybrid system and (b) hybrid module and UV lamp.

HA was changed from $2 \mathrm{mg} / \mathrm{L}$ to $10 \mathrm{mg} / \mathrm{L}$, and kaolin was fixed at $30 \mathrm{mg} / \mathrm{L}$ in the experiment of HA effect. To investigate the roles of PP beads concentration and $\mathrm{pH}$, kaolin and $\mathrm{HA}$ were fixed at $30 \mathrm{mg} / \mathrm{L}$ and $10 \mathrm{mg} / \mathrm{L}$, respectively, in the synthetic feed water. In addition, the water backwashing time (BT) and filtration time (FT) were fixed at $10 \mathrm{~s}$ and $10 \mathrm{~min}$, individually. During the total operation time of $180 \mathrm{~min}$, the permeate flux $(J)$ were measured at each condition. Transmembrane pressure (TMP) was maintained constant at 1.8 bar, the water backwashing pressure at 2.5 bar, the feed flow rate at $1.0 \mathrm{~L} / \mathrm{min}$, and the feed water temperature at $20^{\circ} \mathrm{C}$, in all experiments. The PP beads concentration 
was changed from 0 to $50 \mathrm{~g} / \mathrm{L}$ in the module, to investigate the effect of PP beads and to investigate the $\mathrm{pH}$ effect, the $\mathrm{pH}$ was changed from 5 to 9 in the synthetic feed water.

To evaluate the treatment efficiencies of turbid materials and DOM, the quality of feed and treated water was analyzed for each experiment. To measure turbid materials and DOM, turbidity was measured using a turbidimeter (2100N, Hach, Ames, IA, USA) and $\mathrm{UV}_{254}$ absorbance was analyzed using a UV spectrophotometer (Genesys 10 UV, Thermo, Pittsburgh, PA, USA). The detection limits of turbidimeter and UV spectrophotometer were 0 to $4000 \mathrm{NTU}( \pm 0.001 \mathrm{NTU})$ and -0.1 to $3.0 \mathrm{~cm}^{-1}$ $\left( \pm 0.001 \mathrm{~cm}^{-1}\right)$ correspondingly. Before measuring $\mathrm{UV}_{254}$ absorbance, each sample was filtered using a $0.2 \mu \mathrm{m}$ syringe filter to remove turbid materials.

To clean the ceramic membrane and apparatus after each experiment was finished, all of the synthetic solution was discharged from the hybrid water treatment system, and distilled water was circulated through the line of the system for $15 \mathrm{~min}$. To combust fouling materials inside the membrane, the PP beads and the membrane were separated from the module, and the membrane was ignited at $550^{\circ} \mathrm{C}$ in a furnace for $30 \mathrm{~min}$. To wash out organic or inorganic pollutants after cooling the membrane, the membrane was immersed in a nitric acid $\left(\mathrm{HNO}_{3}\right)$ of $15 \%$ for $24 \mathrm{~h}$, and in a sodium hydroxide $(\mathrm{NaOH})$ solution of $0.25 \mathrm{~N}$ for $3 \mathrm{~h}$, and kept in distilled water for $24 \mathrm{~h}$ for rinsing. Before beginning a new experiment, the water permeated flux $\left(J_{w}\right)$ was measured to check the membrane recovery when a normal operation was performed with distilled water, after the recovered membrane was installed inside the module. The recovered membrane was used in all of the experiments to reduce the influence of membrane condition on the treatment efficiency.

\section{Results and Discussions}

The effects of HA, pure PP beads concentration, and $\mathrm{pH}$ were investigated in the hybrid water treatment process of seven-channel alumina MF (HC10) membrane and pure PP beads with periodic water backwashing and UV irradiation. Membrane resistance, boundary layer, and membrane fouling $\left(R_{m}, R_{b}\right.$, and $\left.R_{f}\right)$ were calculated from permeate flux $(J)$ data using the resistance-in-series filtration equation $\left(J=\Delta P /\left(R_{m}+R_{b}+R_{f}\right)\right)$ which was the same method as the previous study [24], where $\Delta P$ is the transmembrane pressure. For a new membrane, the equation was simplified to $J=\Delta P / R_{m}$ because there were no boundary layer resistances, and membrane fouling and $R_{m}$ could be determined using $J$ data for a new membrane. For the synthetic water of HA and kaolin, the equation was modified to $J=\Delta P /\left(R_{m}+R_{b}\right)$ at initial time, and $R_{b}$ could be determined using $J_{0}$ and $R_{m}$ data. Irreversible and reversible membrane fouling resistances $\left(R_{i f}, R_{r f}\right)$ could be found from $J$ data after physical washing using a brush inside the membrane.

\subsection{Effect of HA Concentration on Membrane Fouling and Treatment Efficiency}

The membrane fouling resistance $\left(R_{f}\right)$ was significantly influenced by humic acid (HA), which was one of the major natural organic matters $(\mathrm{NOM})$ in lakes or rivers, and $R_{f}$ was the minimum at HA $0 \mathrm{~g} / \mathrm{L}$, and almost constant at 2 to $6 \mathrm{mg} / \mathrm{L}$ of $\mathrm{HA}$; however, it increased dramatically with an increase in the concentration of HA from $6 \mathrm{mg} / \mathrm{L}$ to $8 \mathrm{mg} / \mathrm{L}$, and then, decreased suddenly in a concentration of HA from $8 \mathrm{mg} / \mathrm{L}$ to $10 \mathrm{mg} / \mathrm{L}$, as shown in Figure 2a. This means that DOM, similar to HA, could drive membrane fouling more severely on the surface and inside the alumina membrane, with an increase of HA concentration from $6 \mathrm{mg} / \mathrm{L}$ to $8 \mathrm{mg} / \mathrm{L}$ in water. However, the membrane fouling decreased from $8 \mathrm{mg} / \mathrm{L}$ to $10 \mathrm{mg} / \mathrm{L}$ of $\mathrm{HA}$, because the thick fouling cake on the membrane could be removed by water backwashing at $10 \mathrm{mg} / \mathrm{L}$ of HA. As summarized in Table 2, the membrane resistance $\left(R_{m}\right)$ was controlled at a constant value by combustion in a furnace and washing with an acid and alkali solution. The final $R_{f}\left(R_{f, 180}\right)$ value after operating for $180 \mathrm{~min}$ at HA $8 \mathrm{mg} / \mathrm{L}$ was $1.963 \times 10^{9} \mathrm{~kg} / \mathrm{m}^{2} \mathrm{~s}$, which was 3.24 times higher than $0.606 \times 10^{9} \mathrm{~kg} / \mathrm{m}^{2} \mathrm{~s}$ of the $R_{f, 180}$ value at HA $0 \mathrm{mg} / \mathrm{L}$. 


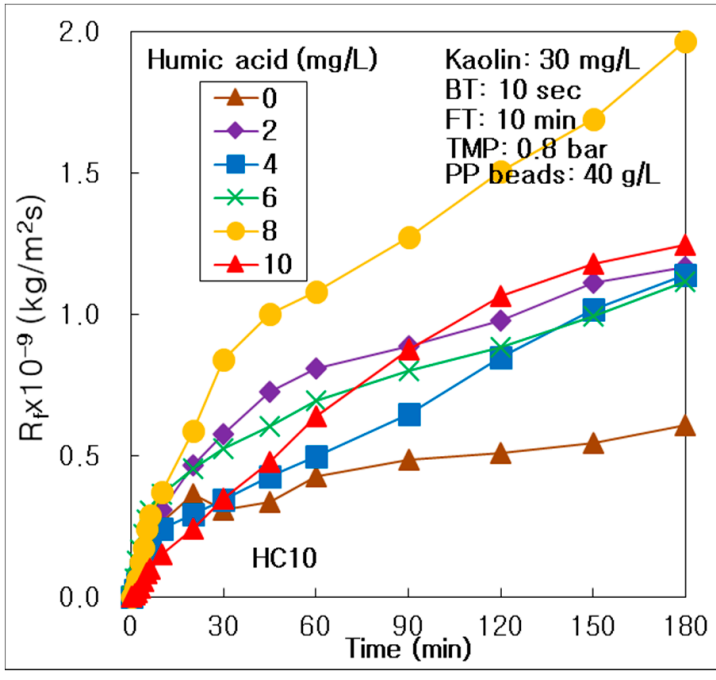

(a)

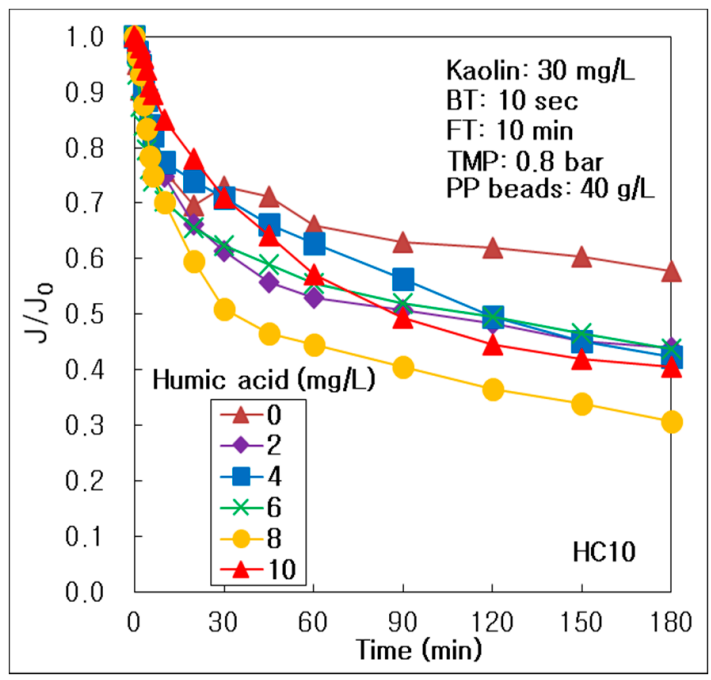

(b)

Figure 2. Effect of humic acid concentration in the hybrid process of multichannel alumina MF and PP beads with UV irradiation and periodic water backwashing: (a) Resistance of membrane fouling and (b) dimensionless permeate flux.

In the previous study [22] for the hybrid water treatment process of the same tubular carbon fiber UF and the same pure PP beads, $R_{f}$ increased dramatically with an increase in the concentration of HA from $2 \mathrm{mg} / \mathrm{L}$ to $10 \mathrm{mg} / \mathrm{L}$. The increasing rate of $R_{f}$ was very high, when HA increased from $6 \mathrm{mg} / \mathrm{L}$ to $10 \mathrm{mg} / \mathrm{L}$, in particular. This means that DOM, similar to HA, could drive membrane fouling more severely on the surface and inside the carbon fiber membrane, with an increase of HA concentration in water, and specifically at a high HA concentration. There was a little different trend as compared with the study of $\mathrm{HC10}$, depending on the membrane type and material. The $R_{f, 180}$ value after operating for $180 \mathrm{~min}$ at HA $10 \mathrm{mg} / \mathrm{L}$ was $6.998 \times 10^{9} \mathrm{~kg} / \mathrm{m}^{2} \mathrm{~s}$, which was 3.94 times higher than $1.775 \times 10^{9} \mathrm{~kg} / \mathrm{m}^{2} \mathrm{~s}$ of the $R_{f, 180}$ value at HA $2 \mathrm{mg} / \mathrm{L}$. The $R_{f, 180}$ value was much higher than those of this result of HC10 in this study, meaning that membrane fouling could be much less developed in the seven-channel HC10 membrane as compared with the tubular C005 membrane.

As shown in Figure $2 \mathrm{~b}$, the dimensionless permeate flux $\left(J / J_{0}\right)$, where $J_{0}$ was the initial permeate flux predicted using the initial two data by an extrapolation method, was plotted according to HA concentration. The $J / J_{0}$ overlapped in the range of HA 2 to $6 \mathrm{mg} / \mathrm{L}$, and it showed the highest values at HA $0 \mathrm{mg} / \mathrm{L}$ and the lowest at HA $8 \mathrm{mg} / \mathrm{L}$ during $180 \mathrm{~min}$; however, it was much higher at HA $10 \mathrm{mg} / \mathrm{L}$. This means that the permeate flux could be maintained low at HA $8 \mathrm{mg} / \mathrm{L}$ and increased at $\mathrm{HA} 10 \mathrm{mg} / \mathrm{L}$, because the membrane fouling was developed severely by DOM, and the cake layer could be removed at $\mathrm{HA} 10 \mathrm{mg} / \mathrm{L}$ by water backwashing.

As arranged in Table 2, the final $J / J_{0}$ after operating for $180 \mathrm{~min}\left(J_{180} / J_{0}\right)$ was 0.578 at $\mathrm{HA} 0 \mathrm{mg} / \mathrm{L}$, which was 1.88 times higher than 0.307 at $\mathrm{HA} 8 \mathrm{mg} / \mathrm{L}$. In the previous work [22] of the C005, J/J $J_{0}$ tended to decrease with an increase in the HA concentration from 2 to $10 \mathrm{mg} / \mathrm{L}$, specifically from 6 to $8 \mathrm{mg} / \mathrm{L}$, because of the membrane fouling development by the more DOM. The $J_{180} / J_{0}$ was 0.241 at HA $2 \mathrm{mg} / \mathrm{L}$, which was 2.84 times higher than 0.085 at HA $10 \mathrm{mg} / \mathrm{L}$. This means that the permeate flux decline rate was affected more severely by HA concentration in the hybrid process of $\mathrm{C} 005$ than HC10, because the membrane fouling increased dramatically with an increase in HA concentration.

In addition, the permeate volume $\left(V_{T}\right)$ of $14.18 \mathrm{~L}$ at $\mathrm{HA} 0 \mathrm{mg} / \mathrm{L}$ was 1.57 times higher than $9.05 \mathrm{~L}$ of $V_{T}$ at HA $8 \mathrm{mg} / \mathrm{L}$, as shown in Table 2, because high flux was maintained at HA $4 \mathrm{mg} / \mathrm{L}$ during $180 \mathrm{~min}$ as compared in Figure 2b. In [22], the result of the tubular carbon fiber C005, $V_{T}$ at HA $2 \mathrm{mg} / \mathrm{L}$ was $4.98 \mathrm{~L}$, which was 2.59 times higher than $1.92 \mathrm{~L}$ of $V_{T}$ at $\mathrm{HA} 10 \mathrm{mg} / \mathrm{L}$. The difference rate of $V_{T}$ was 
higher in the hybrid process of C005 than HC10. This means that DOM affected membrane fouling more at tubular UF C005 membrane than multichannel MF HC10.

As listed in Table 3, the treatment efficiency of turbidity showed an increasing trend, with an increase of HA concentration. Furthermore, in the result by [22] with C005, the treatment efficiency of turbidity was almost constant. This means that the DOM could affect the treatment of suspended particles, such as kaolin, in the hybrid process of the multichannel alumina MF and the pure PP beads, because the thick membrane fouling layer rejected kaolin particles at a high HA concentration. However, DOM could not affect the process of tubular carbon fiber UF membrane, because of the tubular membrane type.

Table 2. Effect of humic acid (HA) on filtration factors in the hybrid process of seven-channel alumina MF (HC10) membrane and PP beads with periodic water backwashing (BT $10 \mathrm{~s}$, FT $10 \mathrm{~min}$ ) as compared with the results of tubular carbon fiber UF (C005) membrane.

\begin{tabular}{cccccccc}
\hline Membrane & Humic Acid $(\mathbf{m g} / \mathrm{L})$ & $\mathbf{0}$ & $\mathbf{2}$ & $\mathbf{4}$ & $\mathbf{6}$ & $\mathbf{8}$ & $\mathbf{1 0}$ \\
\hline & $R_{m} \times 10^{-9}\left(\mathrm{~kg} / \mathrm{m}^{2} \mathrm{~s}\right)$ & 0.823 & 0.840 & 0.803 & 0.864 & 0.831 & 0.798 \\
& $R_{b} \times 10^{-9}\left(\mathrm{~kg} / \mathrm{m}^{2} \mathrm{~s}\right)$ & 0.006 & 0.072 & 0.030 & 0.001 & 0.038 & 0.053 \\
& $R_{f, 180} \times 10^{-9}\left(\mathrm{~kg} / \mathrm{m}^{2} \mathrm{~s}\right)$ & 0.606 & 1.165 & 1.137 & 1.113 & 1.963 & 1.246 \\
7 channels alumina MF & $R_{i f} \times 10^{-9}\left(\mathrm{~kg} / \mathrm{m}^{2} \mathrm{~s}\right)$ & 0.432 & 0.044 & 0.228 & 0.408 & 0.453 & 1.037 \\
(HC10) & $R_{r f} \times 10^{-9}\left(\mathrm{~kg} / \mathrm{m}^{2} \mathrm{~s}\right)$ & 0.173 & 1.121 & 0.909 & 0.705 & 1.510 & 0.209 \\
& $J_{0}\left(\mathrm{~L} / \mathrm{m}^{2} \mathrm{~h}\right)$ & 341 & 310 & 339 & 326 & 325 & 332 \\
& $J_{180}\left(\mathrm{~L} / \mathrm{m}^{2} \mathrm{~h}\right)$ & 197 & 136 & 143 & 143 & 100 & 135 \\
& $J_{180} / J_{0}$ & 0.578 & 0.439 & 0.423 & 0.437 & 0.307 & 0.406 \\
& $V_{T}(\mathrm{~L})$ & 14.18 & 10.59 & 12.48 & 11.30 & 9.05 & 9.39 \\
\hline \multirow{4}{*}{ Tubular carbon fiber UF } & $R_{m} \times 10^{-9}\left(\mathrm{~kg} / \mathrm{m}^{2} \mathrm{~s}\right)$ & - & 0.429 & 0.397 & 0.418 & 0.418 & 0.415 \\
(C005) [22] & $R_{b} \times 10^{-9}\left(\mathrm{~kg} / \mathrm{m}^{2} \mathrm{~s}\right)$ & - & 0.133 & 0.185 & 0.174 & 0.174 & 0.237 \\
& $R_{f, 180} \times 10^{-9}\left(\mathrm{~kg} / \mathrm{m}^{2} \mathrm{~s}\right)$ & - & 1.775 & 2.135 & 2.676 & 5.311 & 6.998 \\
& $R_{i f} \times 10^{-9}\left(\mathrm{~kg} / \mathrm{m}^{2} \mathrm{~s}\right)$ & - & 0.389 & 0.016 & 0.215 & 0.194 & 0.768 \\
& $R_{r f} \times 10^{-9}\left(\mathrm{~kg} / \mathrm{m}^{2} \mathrm{~s}\right)$ & - & 1.386 & 2.119 & 2.461 & 5.118 & 6.230 \\
& $J_{0}\left(\mathrm{~L} / \mathrm{m}^{2} \mathrm{~h}\right)$ & - & 1129 & 1092 & 1073 & 1072 & 974 \\
& $J_{180}\left(\mathrm{~L} / \mathrm{m}^{2} \mathrm{~h}\right)$ & - & 272 & 234 & 194 & 108 & 83 \\
& $J_{180} / J_{0}$ & - & 0.241 & 0.214 & 0.181 & 0.100 & 0.085 \\
& $V_{T}(\mathrm{~L})$ & - & 4.98 & 4.89 & 3.83 & 2.67 & 1.92 \\
\hline
\end{tabular}

Table 3. Water quality and treatment efficiency of turbidity in the hybrid process of 7-channel alumina MF (HC10) and PP beads for the effect of humic acid concentration as compared with results of tubular carbon fiber UF (C005) membrane.

\begin{tabular}{cccccccc}
\hline & & \multicolumn{4}{c}{ Turbidity (NTU) } & \multicolumn{2}{c}{ Average Treatment Efficiency (\%) } \\
\cline { 3 - 7 } $\begin{array}{c}\text { Kaolin } \\
(\mathbf{m g} / \mathbf{L})\end{array}$ & $\begin{array}{c}\text { Humic Acid } \\
(\mathbf{m g} / \mathbf{L})\end{array}$ & \multicolumn{2}{c}{ Feed Water } & \multicolumn{2}{c}{ Treated Water } & \multicolumn{2}{c}{ Adsorption Media } \\
\cline { 3 - 7 } & & Range & Average & Range & Average & 7 Channels & Tubular Carbon \\
Alumina MF & Fiber UF [22] \\
\hline & 0 & $12.1-13.5$ & 12.6 & $0.342-0.396$ & 0.371 & 97.0 & - \\
& 2 & $12.1-16.3$ & 13.6 & $0.370-0.446$ & 0.396 & 97.1 & 99.1 \\
& 4 & $18.2-24.5$ & 20.9 & $0.312-0.549$ & 0.397 & 98.1 & 98.0 \\
30 & 6 & $13.2-20.2$ & 15.6 & $0.187-0.469$ & 0.260 & 98.3 & 98.9 \\
& 8 & $23.9-37.2$ & 31.1 & $0.324-0.534$ & 0.415 & 98.7 & 98.0 \\
& 10 & $24.5-32.4$ & 29.4 & $0.391-0.557$ & 0.457 & 98.4 & 99.0 \\
\hline
\end{tabular}

As shown in Table 4, the treatment efficiency of $\mathrm{UV}_{254}$ absorbance, which means the concentration of DOM, increased with an increase in HA concentration, and finally showed the maximum $49.7 \%$ at HA $10 \mathrm{mg} / \mathrm{L}$. This means that DOM could be treated more effectively at a high DOM condition in the hybrid water treatment process of seven-channel alumina MF and pure PP beads. The maximum treatment efficiency of DOM was $69.3 \%$ at HA $6 \mathrm{mg} / \mathrm{L}$, in the previous work [22] for the hybrid process of the tubular carbon fiber MF membrane and the same PP beads. From $2 \mathrm{mg} / \mathrm{L}$ to $6 \mathrm{mg} / \mathrm{L}$ of HA, most of DOM could be adsorbed on fouling materials inside the membrane or retained by cake layer 
on the membrane, and the remained things passed through the membrane adsorbed or oxidized by the PP beads and UV. It happened that the treated water quality of HA increased less slowly than the feed water quality. However, above $6 \mathrm{mg} / \mathrm{L}$ of HA, most of DOM passed through the membrane and could not be treated by adsorption or photooxidation by the PP beads and UV. And the treated water quality of HA increased more rapidly than the feed water quality.

Table 4. Water quality and treatment efficiency of dissolved organic matter (DOM) $\left(\mathrm{UV}_{254}\right.$ absorbance) in the hybrid process of 7-channel alumina MF (HC10) and PP beads for the effect of humic acid concentration as compared with results of tubular carbon fiber UF (C005) membrane.

\begin{tabular}{|c|c|c|c|c|c|c|c|}
\hline \multirow{3}{*}{$\begin{array}{l}\text { Kaolin } \\
(\mathrm{mg} / \mathrm{L})\end{array}$} & \multirow{3}{*}{$\begin{array}{l}\text { Humic Acid } \\
\text { (mg/L) }\end{array}$} & \multicolumn{4}{|c|}{$\begin{array}{c}\mathrm{UV}_{254} \text { Absorbance } \\
\left(\mathrm{cm}^{-1}\right)\end{array}$} & \multirow{2}{*}{\multicolumn{2}{|c|}{$\begin{array}{c}\text { Average Treatment Efficiency (\%) } \\
\text { Adsorption Media }\end{array}$}} \\
\hline & & \multicolumn{2}{|c|}{ Feed Water } & \multicolumn{2}{|c|}{ Treated Water } & & \\
\hline & & Range & Average & Range & Average & $\begin{array}{l}7 \text { Channels } \\
\text { Alumina MF }\end{array}$ & $\begin{array}{c}\text { Tubular Carbon } \\
\text { Fiber UF [22] }\end{array}$ \\
\hline \multirow{6}{*}{30} & 0 & $0.003-0.005$ & 0.004 & $0.002-0.004$ & 0.003 & 14.3 & - \\
\hline & 2 & $0.147-0.176$ & 0.161 & $0.110-0.140$ & 0.131 & 18.6 & 67.2 \\
\hline & 4 & $0.132-0.241$ & 0.164 & $0.121-0.147$ & 0.132 & 19.5 & 65.9 \\
\hline & 6 & $0.164-0.211$ & 0.186 & $0.131-0.151$ & 0.145 & 22.0 & 69.3 \\
\hline & 8 & $0.184-0.370$ & 0.244 & $0.135-0.152$ & 0.146 & 40.3 & 59.3 \\
\hline & 10 & $0.203-0.302$ & 0.247 & $0.110-0.142$ & 0.124 & 49.7 & 60.9 \\
\hline
\end{tabular}

\subsection{Effect of Pure PP Beads on Membrane Fouling and Treatment Efficiency}

In this study, the pure PP beads were induced for adsorption of DOM and turbid matters. The effect of pure PP beads concentration was investigated at the most severe HA $10 \mathrm{mg} / \mathrm{L}$ condition, at kaolin $30 \mathrm{mg} / \mathrm{L}$, and $\mathrm{pH}$ 7. The membrane fouling resistances $\left(R_{f}\right)$ showed the highest at $50 \mathrm{~g} / \mathrm{L}$ and the lowest at $5 \mathrm{~g} / \mathrm{L}$ during the $180 \mathrm{~min}$ operation, as shown in Figure 3a. This means that the optimal PP beads concentration could be $5 \mathrm{~g} / \mathrm{L}$ to control the membrane fouling and high permeate flux in this hybrid process of 7-channel alumina MF HC10 and PP beads.

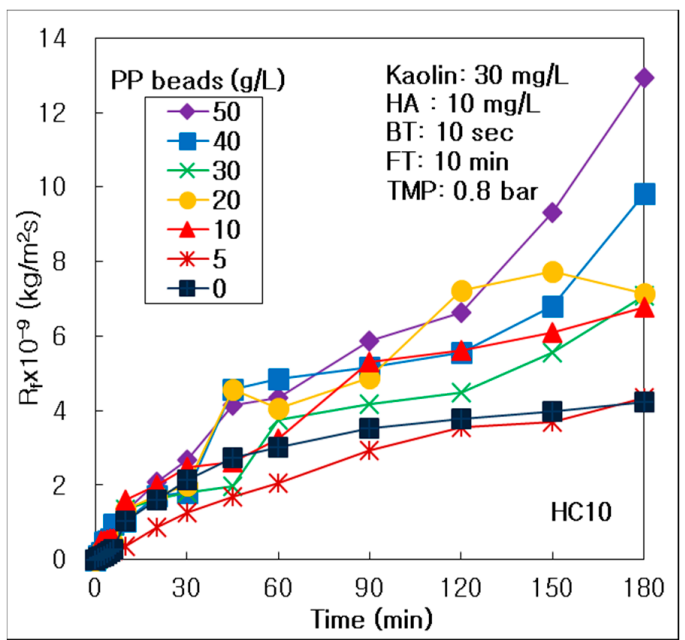

(a)

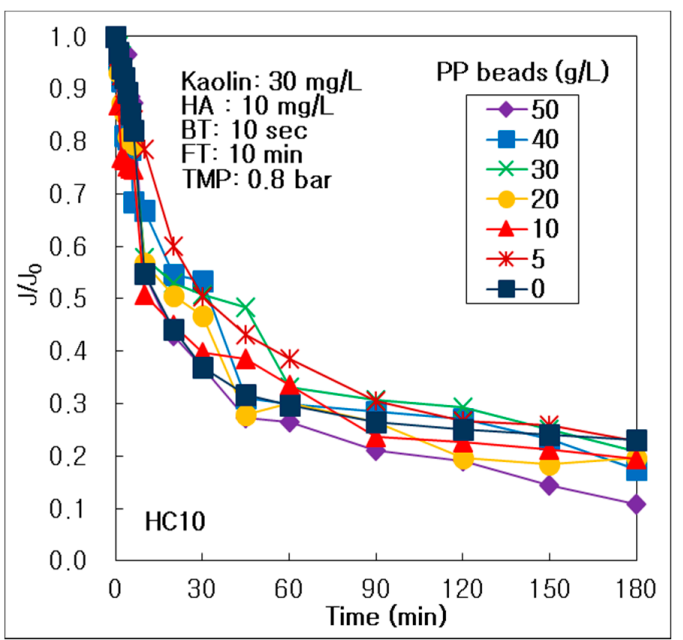

(b)

Figure 3. Effect of PP beads concentration in the hybrid process of multichannel alumina MF and PP beads with UV irradiation and periodic water backwashing: (a) Resistance of membrane fouling and (b) dimensionless permeate flux.

In the previous work by [23] for the hybrid process of the tubular carbon fiber UF C005 and the same PP beads, the $R_{f}$ showed the highest at $50 \mathrm{~g} / \mathrm{L}$ during the $180 \mathrm{~min}$ operation, and the lowest at $5 \mathrm{~g} / \mathrm{L}$ until $120 \mathrm{~min}$, and at $0 \mathrm{~g} / \mathrm{L}$ of PP beads after $120 \mathrm{~min}$. This result almost agreeds with the trend of PP beads effect in this study and showed that the effect of PP beads concentration on membrane 
fouling could not depend on the membrane type and materials in this hybrid water treatment process of ceramic membrane and pure PP beads.

In the hybrid process of ceramic membrane and PP beads, the boundary layer resistance $\left(R_{b}\right)$, which was produced by concentration polarization on the membrane surface, was the lowest at $50 \mathrm{~g} / \mathrm{L}$ of PP beads independent of membrane type and materials, as shown in Table 5. This means that the frequent colliding of more PP beads on the membrane surface could reduce the concentration polarization for both $\mathrm{HC10}$ and C005. The $R_{f, 180}$ after $180 \mathrm{~min}$ was the highest, i.e., $12.94 \times 10^{9} \mathrm{~kg} / \mathrm{m}^{2} \mathrm{~s}$, at $50 \mathrm{~g} / \mathrm{L}$, which was 3.06 times higher than $4.23 \times 10^{9} \mathrm{~kg} / \mathrm{m}^{2} \mathrm{~s}$ for the $R_{f, 180}$ at $0 \mathrm{~g} / \mathrm{L}$ of PP beads. The $R_{r f}$ showed an increasing trend, with an increasing PP beads concentration from $0 \mathrm{~g} / \mathrm{L}$ to $50 \mathrm{~g} / \mathrm{L}$; however, the minimum $R_{i f}$ was at $40 \mathrm{~g} / \mathrm{L}$ and the maximum was at $0 \mathrm{~g} / \mathrm{L}$ of PP beads. This means that the reversible membrane fouling could be inhibited at $50 \mathrm{~g} / \mathrm{L}$ of PP beads, because the optimal amount of PP beads captured the turbid or organic materials by adsorption.

In the previous result by [23] for the hybrid process of the C005 and the pure PP beads, the $R_{f, 180}$ after $180 \mathrm{~min}$ was the highest of $4.892 \times 10^{9} \mathrm{~kg} / \mathrm{m}^{2} \mathrm{~s}$ at $50 \mathrm{~g} / \mathrm{L}$, which was 1.48 times higher than $3.306 \times 10^{9} \mathrm{~kg} / \mathrm{m}^{2} \mathrm{~s}$ of the $R_{f, 180}$ at $0 \mathrm{~g} / \mathrm{L}$ of PP beads. These $R_{f, 180}$ were much higher than those of $\mathrm{HC} 10$ in this study; however, the trends depending on PP beads concentration was exactly the same in this hybrid process. Additionally, the $R_{r f}$ increased with an increasing PP beads concentration from $0 \mathrm{~g} / \mathrm{L}$ to $50 \mathrm{~g} / \mathrm{L}$ of PP beads; however, the $R_{\text {if }}$ was the minimum at $50 \mathrm{~g} / \mathrm{L}$ and the maximum at $10 \mathrm{~g} / \mathrm{L}$ of PP beads. This result was also almost in agreement with that of this study using HC10.

The $J / J_{0}$ was compared to investigate the effect of PP beads on the relative decline of permeate flux, as shown in Figure $3 \mathrm{~b}$. The $J / J_{0}$ maintained higher until 90 min at PP beads $5 \mathrm{~g} / \mathrm{L}$ than those at other PP beads concentration, and showed the lowest at PP beads $50 \mathrm{~g} / \mathrm{L}$ after $60 \mathrm{~min}$. As arranged in Table 5, the $J_{0}$ and $J_{180}$ decreased to $40 \mathrm{~g} / \mathrm{L}$ and to $50 \mathrm{~g} / \mathrm{L}$, respectively, with an increase in PP beads concentration, because the $R_{b}$ and $R_{f}$ increased to $40 \mathrm{~g} / \mathrm{L}$ and to $50 \mathrm{~g} / \mathrm{L}$ of PP beads, correspondingly. Finally, the $J_{180} / J_{0}$ after $180 \mathrm{~min}$ of operation at $0 \mathrm{~g} / \mathrm{L}$ of the PP beads was the maximum 0.230 , which was 2.13 times higher than 0.108 at $50 \mathrm{~g} / \mathrm{L}$. However, the $V_{T}$ was the highest, $11.75 \mathrm{~L}$ at $5 \mathrm{~g} / \mathrm{L}$ of PP beads, because $J$ maintained higher all through the operation than those of other PP beads conditions.

In the previous work by [23] for the hybrid process of the C005 and the pure PP beads, the $J / J_{0}$ showed higher during the 5 to $90 \mathrm{~min}$ at $5 \mathrm{~g} / \mathrm{L}$ than those at other PP beads concentration. The $J_{0}$ decreased and $J_{180}$ increased as increasing PP beads concentration, because the $R_{b}$ was the minimum at $50 \mathrm{~g} / \mathrm{L}$ of PP beads. In addition, the $J_{180} / J_{0}$ after $180 \mathrm{~min}$ of operation at $0 \mathrm{~g} / \mathrm{L}$ of the PP beads was the maximum 0.126 , which was 1.62 times higher than 0.078 at $50 \mathrm{~g} / \mathrm{L}$. The increasing rate, 1.62 of $J_{180} / J_{0}$ for C005, was much lower than 2.13 for HC10, because PP beads controlled more effectively the membrane fouling in the hybrid process of $\mathrm{HC} 10$ than C005. Also, the $V_{T}$ was the highest $4.99 \mathrm{~L}$ at $5 \mathrm{~g} / \mathrm{L}$ of PP beads for the $\mathrm{C} 005$ process, which was the exact same trend of $\mathrm{HC} 10$ in this study.

As arranged in Table 6, the treatment efficiencies of turbidity were almost constant in the range of $97.5 \%$ and $98.9 \%$ in the hybrid process of HC10 MF, independent of the pure PP beads concentration. This means that the tubid matters could be treated effectively, independent of PP beads concentration in this hybrid process. In the previous result by [23] for the hybrid process of the C005 and the pure PP beads, the treatment efficiencies of turbidity were the highest, i.e., $99.3 \%$ at $30 \mathrm{~g} / \mathrm{L}$. This means that the optimal PP beads concentration could be $30 \mathrm{~g} / \mathrm{L}$ to treat the turbid matter in the hybrid process of C005 UF membrane. 
Table 5. Effect of PP beads concentration on filtration factors in the hybrid process of 7-channel alumina MF (HC10) membrane and PP beads with periodic water backwashing (BT $10 \mathrm{~s}$, FT $10 \mathrm{~min}$ ) as compared with the results of tubular carbon fiber UF (C005) membrane.

\begin{tabular}{ccccccccc}
\hline Membrane & PP Beads $(\mathrm{g} / \mathrm{L})$ & $\mathbf{0}$ & $\mathbf{5}$ & $\mathbf{1 0}$ & $\mathbf{2 0}$ & $\mathbf{3 0}$ & $\mathbf{4 0}$ & $\mathbf{5 0}$ \\
\hline & $R_{m} \times 10^{-9}\left(\mathrm{~kg} / \mathrm{m}^{2} \mathrm{~s}\right)$ & 1.24 & 1.27 & 1.53 & 1.75 & 1.82 & 1.93 & 1.49 \\
& $R_{b} \times 10^{-9}\left(\mathrm{~kg} / \mathrm{m}^{2} \mathrm{~s}\right)$ & 0.020 & 0.024 & 0.106 & 0.009 & 0.041 & 0.142 & 0.076 \\
& $R_{f, 180} \times 10^{-9}\left(\mathrm{~kg} / \mathrm{m}^{2} \mathrm{~s}\right)$ & 4.23 & 4.35 & 6.79 & 7.15 & 7.09 & 9.83 & 12.94 \\
7-channel & $R_{i f} \times 10^{-9}\left(\mathrm{~kg} / \mathrm{m}^{2} \mathrm{~s}\right)$ & 1.75 & 1.24 & 1.20 & 3.24 & 0.66 & 0.43 & 1.44 \\
alumina & $R_{r f} \times 10^{-9}\left(\mathrm{~kg} / \mathrm{m}^{2} \mathrm{~s}\right)$ & 2.486 & 3.110 & 5.587 & 3.910 & 6.423 & 9.403 & 11.500 \\
MF (HC10) & $J_{0}\left(\mathrm{~L} / \mathrm{m}^{2} \mathrm{~h}\right)$ & 503 & 491 & 388 & 361 & 342 & 307 & 405 \\
& $J_{180}\left(\mathrm{~L} / \mathrm{m}^{2} \mathrm{~h}\right)$ & 116 & 113 & 75 & 71 & 71 & 53 & 44 \\
& $J_{180} / J_{0}$ & 0.230 & 0.229 & 0.194 & 0.198 & 0.208 & 0.174 & 0.108 \\
& $V_{T}(\mathrm{~L})$ & 10.11 & 11.75 & 7.56 & 6.94 & 7.91 & 6.55 & 6.85 \\
\hline & $R_{m} \times 10^{-9}\left(\mathrm{~kg} / \mathrm{m}^{2} \mathrm{~s}\right)$ & 0.413 & 0.409 & 0.409 & 0.411 & 0.403 & 0.405 & 0.403 \\
Tubular & $R_{b} \times 10^{-9}\left(\mathrm{~kg} / \mathrm{m}^{2} \mathrm{~s}\right)$ & 0.062 & 0.043 & 0.119 & 0.031 & 0.042 & 0.048 & 0.009 \\
carbon & $R_{f, 180} \times 10^{-9}\left(\mathrm{~kg} / \mathrm{m}^{2} \mathrm{~s}\right)$ & 3.306 & 3.596 & 3.683 & 4.767 & 4.967 & 4.918 & 4.892 \\
fiber UF & $R_{i f} \times 10^{-9}\left(\mathrm{~kg} / \mathrm{m}^{2} \mathrm{~s}\right)$ & 0.008 & 0.004 & 0.021 & 0.006 & 0.015 & 0.020 & 0.002 \\
(C005) [23] & $R_{r f} \times 10^{-9}\left(\mathrm{~kg} / \mathrm{m}^{2} \mathrm{~s}\right)$ & 3.298 & 3.596 & 3.662 & 4.761 & 4.953 & 4.898 & 4.890 \\
& $J_{0}\left(\mathrm{~L} / \mathrm{m}^{2} \mathrm{~h}\right)$ & 1336 & 1407 & 1221 & 1435 & 1426 & 1401 & 1543 \\
& $J_{180}\left(\mathrm{~L} / \mathrm{m}^{2} \mathrm{~h}\right)$ & 168 & 157 & 151 & 122 & 117 & 118 & 120 \\
& $J_{180} / J_{0}$ & 0.126 & 0.112 & 0.124 & 0.085 & 0.082 & 0.084 & 0.078 \\
& $V_{T}(\mathrm{~L})$ & 4.13 & 4.99 & 3.54 & 3.35 & 2.73 & 3.16 & 3.29 \\
\hline
\end{tabular}

Table 6. Water quality and treatment efficiency of turbidity in the hybrid process of 7-channel alumina $\mathrm{MF}$ (HC10) and PP beads for the effect of PP beads concentration as compared with results of tubular carbon fiber UF (C005) membrane.

\begin{tabular}{ccccccc}
\hline \multirow{2}{*}{$\begin{array}{c}\text { PP Beads } \\
\text { (g/L) }\end{array}$} & \multicolumn{4}{c}{ Turbidity (NTU) } & \multicolumn{2}{c}{ Average Treatment Efficiency (\%) } \\
\cline { 2 - 5 } & \multicolumn{2}{c}{ Feed Water } & \multicolumn{2}{c}{ Treated Water } & \multirow{2}{*}{$\begin{array}{c}\text { 7 Channels } \\
\text { Alumina MF }\end{array}$} & $\begin{array}{c}\text { Tubular Carbon } \\
\text { Fiber UF [23] }\end{array}$ \\
\cline { 2 - 5 } & Range & Average & Range & Average & & \\
\hline 0 & $20.6-25.9$ & 23.1 & $0.207-0.326$ & 0.264 & 98.9 & 98.6 \\
5 & $22.8-27.3$ & 25.5 & $0.338-0.587$ & 0.438 & 98.3 & 98.5 \\
10 & $22.8-25.7$ & 24.4 & $0.297-0.434$ & 0.349 & 98.6 & 99.1 \\
20 & $20.7-28.8$ & 24.0 & $0.298-0.408$ & 0.341 & 98.6 & 97.9 \\
30 & $15.3-20.4$ & 17.8 & $0.353-0.542$ & 0.447 & 97.5 & 99.3 \\
40 & $22.8-25.8$ & 24.1 & $0.254-0.333$ & 0.297 & 98.8 & 98.7 \\
50 & $27.3-34.3$ & 29.7 & $0.308-0.354$ & 0.339 & 98.9 & 98.4 \\
\hline
\end{tabular}

As shown in Table 7, the treatment efficiency of DOM ( $\mathrm{UV}_{254}$ absorbance) did not show a trend; however, that was the maximal of $51.3 \%$ at $5 \mathrm{~g} / \mathrm{L}$ of PP beads. This proves that the optimal PP beads concentration was $5 \mathrm{~g} / \mathrm{L}$ to remove DOM in this hybrid process of HC10 MF and pure PP beads. In the previous work by [23] for the hybrid process of the C005 and the pure PP beads, the treatment efficiency of DOM showed a trend to increase dramatically from $75.9 \%$ to $84.1 \%$, with an increase in the PP beads concentration. It was much higher than those for the hybrid HC10 MF process in this study, because the secondary gel layer could be formed denser on the UF membrane surface of smaller pore size than MF. Finally, the more PP beads could adsorb the more efficiently DOM on the surface of PP beads in the hybrid C005 UF process. 
Table 7. Water quality and treatment efficiency of DOM $\left(\mathrm{UV}_{254}\right.$ absorbance) in the hybrid process of 7-channel alumina MF (HC10) and PP beads for the effect of PP beads concentration as compared with results of tubular carbon fiber UF (C005) membrane.

\begin{tabular}{ccccccc}
\hline \multirow{2}{*}{$\begin{array}{c}\text { PP Beads } \\
(\mathbf{g} / \mathbf{L})\end{array}$} & \multicolumn{3}{c}{$\mathbf{U V}_{\mathbf{2 5 4}}$ Absorbance $\mathbf{( c m}^{-\mathbf{1}} \mathbf{c}$} & \multicolumn{2}{c}{ Average Treatment Efficiency (\%) } \\
\cline { 2 - 5 } & \multicolumn{2}{c}{ Feed Water } & \multicolumn{2}{c}{ Treated Water } & \multirow{2}{*}{ 7 Channels } & Tubular Carbon \\
\cline { 2 - 5 } & Range & Average & Range & Average & Alumina MF & Fiber UF [23] \\
\hline 0 & $0.339-0.411$ & 0.389 & $0.145-0.265$ & 0.205 & 47.4 & 75.9 \\
5 & $0.498-0.569$ & 0.526 & $0.214-0.298$ & 0.256 & 51.3 & 77.0 \\
10 & $0.399-0.487$ & 0.431 & $0.185-0.251$ & 0.220 & 48.9 & 77.8 \\
20 & $0.305-0.363$ & 0.342 & $0.155-0.228$ & 0.182 & 46.8 & 83.2 \\
30 & $0.403-0.598$ & 0.527 & $0.192-0.423$ & 0.273 & 48.1 & 82.3 \\
40 & $0.318-0.359$ & 0.335 & $0.154-0.177$ & 0.168 & 49.8 & 82.4 \\
50 & $0.310-0.410$ & 0.374 & $0.159-0.215$ & 0.200 & 46.5 & 84.1 \\
\hline
\end{tabular}

\subsection{Effect of $\mathrm{pH}$ on Membrane Fouling and Treatment Efficiency}

To investigate the $\mathrm{pH}$ effect on membrane fouling and treatment efficiency, the $\mathrm{pH}$ of synthetic feed water was controlled by nitric acid $\left(\mathrm{HNO}_{3}\right)$ and sodium hydroxide $(\mathrm{NaOH})$. As shown in Figure $4 \mathrm{a}$, the $R_{f}$ maintained the highest values at $\mathrm{pH} 9$, and the lowest at $\mathrm{pH} 5$ during $180 \mathrm{~min}$. There was a dramatic trend to increase as the $\mathrm{pH}$ increased from 5 to 9 in the hybrid process of HC10 MF. As arranged in Table 8, the $R_{f, 180}$ and $\mathrm{R}_{\mathrm{rf}}$ were the minimum at $\mathrm{pH} 5$; however, the $R_{b}$ was the lowest at $\mathrm{pH}$ 6. Conclusively, the $R_{f, 180}$ increased dramatically with an increase in $\mathrm{pH}$, and was the highest, $20.20 \times 10^{9} \mathrm{~kg} / \mathrm{m}^{2} \mathrm{~s}$, at $\mathrm{pH} 9$, which was 4.58 times higher than $4.41 \times 10^{9} \mathrm{~kg} / \mathrm{m}^{2} \mathrm{~s}$ at pH 6 . The $R_{r f}$ and $R_{\text {if }}$ were the maximum at $\mathrm{pH} 9$ and $\mathrm{pH} 8$, respectively. This means that the reversible and irreversible membrane fouling, and concentration polarization could be inhibited at acid condition, because both the membrane and humic materials had a negative surface charge at acid conditions below a $\mathrm{pH}$ of 7, as reported that the surface charge of $\mathrm{ZrO}_{2}$ membrane was changed depending on the $\mathrm{pH}$ [25]. The surface charge of seven-channel alumina HC10 membrane, used in this study, could be changed depending on the $\mathrm{pH}$, because those were the similar ceramic membranes as $\mathrm{ZrO}_{2}$ membrane.

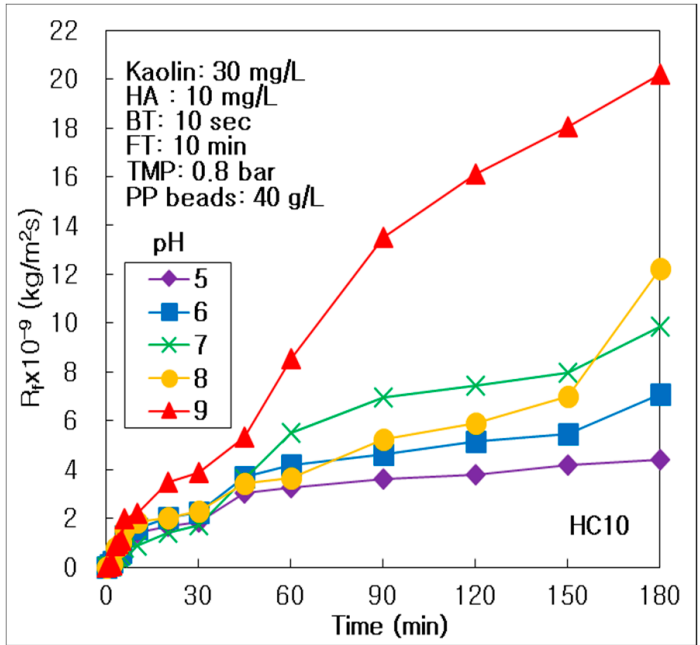

(a)

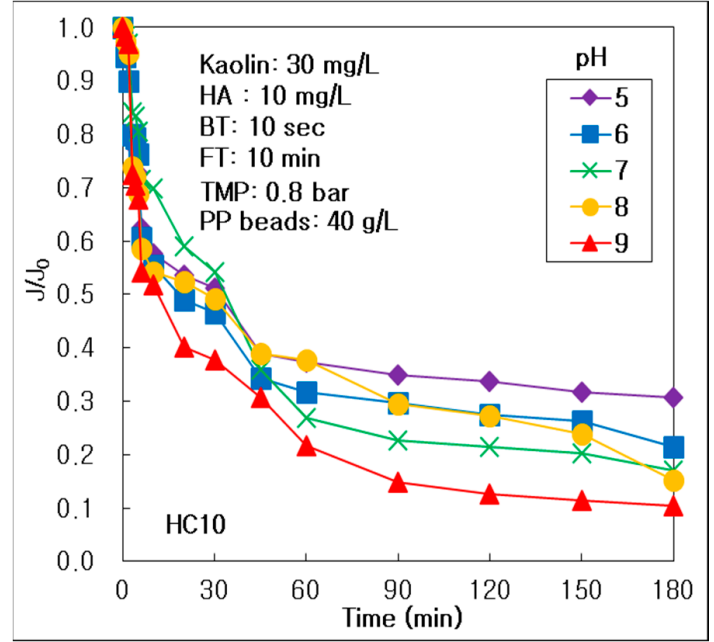

(b)

Figure 4. Effect of $\mathrm{pH}$ on the hybrid process of multichannel alumina MF and PP beads with UV irradiation and periodic water backwashing: (a) Resistance of membrane fouling and (b) dimensionless permeate flux.

In the previous result by [23] for the hybrid process of the C005 and the pure PP beads, the $R_{f}$ showed the highest at a pH of 9 after 90 min and the lowest at a pH of 5 after 150 min, and finally have a 
trend to increase, with an increase in $\mathrm{pH}$ from 5 to 9 . This result agreeds exactly with that in the hybrid process of $\mathrm{HC} 10$ in this study. The $R_{b}$ and $R_{i f}$ were the minimum at a $\mathrm{pH}$ of 5 ; however, the $R_{f, 180}$ and $R_{r f}$ were the lowest at a $\mathrm{pH}$ of 6 . However, this trend did not match the result for HC10 in this study. Conclusively, the $R_{f, 180}$ was the highest, $5.51 \times 10^{9} \mathrm{~kg} / \mathrm{m}^{2} \mathrm{~s}$, at a $\mathrm{pH}$ of 9 , which was 1.32 times higher than $4.16 \times 10^{9} \mathrm{~kg} / \mathrm{m}^{2} \mathrm{~s}$ at a $\mathrm{pH}$ of 6 . The $R_{r f}$ and $R_{i f}$ were the maximum at $\mathrm{pH} 9$. The increasing rate, i.e., 1.32 of $R_{f, 180}$ for $\mathrm{C} 005$ was much lower than 4.58 for $\mathrm{HC} 10$, because $\mathrm{pH}$ controlled more effectively the membrane fouling in the hybrid process of HC10 than C005.

As compared in Figure $4 \mathrm{~b}$ to investigate the $\mathrm{pH}$ effect on relative permeate flux, the $J / J_{0}$ showed a trend to decrease dramatically, with an increase in the $\mathrm{pH}$ from 5 to 9 . The $J_{180} / J_{0}$ after $180 \mathrm{~min}$ of operation at $\mathrm{pH} 5$ was 0.306 , which was 2.94 times higher than 0.104 at $\mathrm{pH} 9$, as shown in Table 8 . And the $J_{180}$ was the maximum $327 \mathrm{~L} / \mathrm{m}^{2} \mathrm{~h}$ at pH 6, and the minimum $270 \mathrm{~L} / \mathrm{m}^{2} \mathrm{~h}$ at $\mathrm{pH} 9$. This means that the high permeate flux could be acquired at $\mathrm{pH} 5$, because the membrane fouling was inhibited by repulsion force between the carbon fiber membrane and humic materials, which had the same negative surface charge, as reported that the surface charge of $\mathrm{ZrO}_{2}$ membrane was changed depending on the $\mathrm{pH}$ [25]. Finally, the $V_{T}$ was the highest of $8.12 \mathrm{~L}$ at $\mathrm{pH} 5$, because the $J$ could maintain highly during a 180 min operation.

In the previous work by [23] for the hybrid process of the C005 and the pure PP beads, the $J_{180} / J_{0}$ after $180 \mathrm{~min}$ of operation at a $\mathrm{pH}$ of 6 was 0.099 , which was 1.46 times higher than 0.068 at a $\mathrm{pH}$ of 9. The increasing rate, 1.42 of $J_{180} / J_{0}$ for $\mathrm{C} 005$, was much lower than 2.94 for $\mathrm{HC} 10$, because the $\mathrm{pH}$ maintained higher the permeate flux in the hybrid process of HC10 than C005. Additionally, $\mathrm{J}_{180}$ was the maximum $138 \mathrm{~L} / \mathrm{m}^{2} \mathrm{~h}$ at a $\mathrm{pH}$ of 6 , and the minimum, $107 \mathrm{~L} / \mathrm{m}^{2} \mathrm{~h}$, at a $\mathrm{pH}$ of 9 . Finally, the $V_{T}$ was the highest of $3.85 \mathrm{~L}$ at $\mathrm{pH} 8$, because the permeate flux could maintain highly during operation. These trends did not match exactly with the result for HC10 in this study, because of the different membrane type and material.

Table 8. Effect of $\mathrm{pH}$ on filtration factors in the hybrid process of 7-channel alumina MF (HC10) membrane and PP beads with periodic water backwashing (BT $10 \mathrm{~s}$, FT $10 \mathrm{~min}$ ) as compared with results of tubular carbon fiber UF (C005) membrane.

\begin{tabular}{|c|c|c|c|c|c|c|}
\hline Membrane & $\mathrm{pH}$ & 5 & 6 & 7 & 8 & 9 \\
\hline \multirow{9}{*}{$\begin{array}{l}\text { 7-channel } \\
\text { alumina MF } \\
\text { (HC10) }\end{array}$} & $R_{m} \times 10^{-9}\left(\mathrm{~kg} / \mathrm{m}^{2} \mathrm{~s}\right)$ & 1.87 & 1.89 & 1.97 & 2.07 & 2.27 \\
\hline & $R_{b} \times 10^{-9}\left(\mathrm{~kg} / \mathrm{m}^{2} \mathrm{~s}\right)$ & 0.071 & 0.060 & 0.065 & 0.136 & 0.080 \\
\hline & $R_{f, 180} \times 10^{-9}\left(\mathrm{~kg} / \mathrm{m}^{2} \mathrm{~s}\right)$ & 4.41 & 7.11 & 9.86 & 12.25 & 20.20 \\
\hline & $R_{i f} \times 10^{-9}\left(\mathrm{~kg} / \mathrm{m}^{2} \mathrm{~s}\right)$ & 0.60 & 0.63 & 0.88 & 3.47 & 0.20 \\
\hline & $R_{r f} \times 10^{-9}\left(\mathrm{~kg} / \mathrm{m}^{2} \mathrm{~s}\right)$ & 3.802 & 6.472 & 8.975 & 8.780 & 19.997 \\
\hline & $J_{0}\left(\mathrm{~L} / \mathrm{m}^{2} \mathrm{~h}\right)$ & 100 & 70 & 53 & 44 & 28 \\
\hline & $J_{180}\left(\mathrm{~L} / \mathrm{m}^{2} \mathrm{~h}\right)$ & 327 & 326 & 313 & 288 & 270 \\
\hline & $J_{180} / J_{0}$ & 0.306 & 0.215 & 0.171 & 0.152 & 0.104 \\
\hline & $V_{T}(\mathrm{~L})$ & 8.12 & 7.00 & 6.30 & 6.26 & 3.87 \\
\hline \multirow{9}{*}{$\begin{array}{c}\text { Tubular } \\
\text { carbon fiber } \\
\text { UF (C005) } \\
{[23]}\end{array}$} & $R_{m} \times 10^{-9}\left(\mathrm{~kg} / \mathrm{m}^{2} \mathrm{~s}\right)$ & 0.412 & 0.413 & 0.405 & 0.405 & 0.401 \\
\hline & $R_{b} \times 10^{-9}\left(\mathrm{~kg} / \mathrm{m}^{2} \mathrm{~s}\right)$ & 0.001 & 0.047 & 0.048 & 0.020 & 0.003 \\
\hline & $R_{f, 180} \times 10^{-9}\left(\mathrm{~kg} / \mathrm{m}^{2} \mathrm{~s}\right)$ & 4.87 & 4.16 & 4.92 & 4.62 & 5.51 \\
\hline & $R_{i f} \times 10^{-9}\left(\mathrm{~kg} / \mathrm{m}^{2} \mathrm{~s}\right)$ & 0.003 & 0.010 & 0.020 & 0.006 & 0.020 \\
\hline & $R_{r f} \times 10^{-9}\left(\mathrm{~kg} / \mathrm{m}^{2} \mathrm{~s}\right)$ & 4.865 & 4.149 & 4.898 & 4.616 & 5.487 \\
\hline & $J_{0}\left(\mathrm{~L} / \mathrm{m}^{2} \mathrm{~h}\right)$ & 1537 & 1382 & 1401 & 1494 & 1573 \\
\hline & $J_{180}\left(\mathrm{~L} / \mathrm{m}^{2} \mathrm{~h}\right)$ & 120 & 138 & 118 & 126 & 107 \\
\hline & $J_{180} / J_{0}$ & 0.078 & 0.099 & 0.084 & 0.084 & 0.068 \\
\hline & $V_{T}(\mathrm{~L})$ & 3.30 & 3.68 & 3.17 & 3.85 & 3.21 \\
\hline
\end{tabular}

As arranged in Table 9, the treatment efficiency of turbidity decreased slightly from $98.6 \%$ to $98.0 \%$, with an increase in $\mathrm{pH}$ from 5 to 9 . This means that the turbid matter, such as kaolin, could be removed more effectively at acidic $\mathrm{pH}$ conditions in the hybrid process of the alumina HC10 MF membrane with periodic water backwashing. Y. Zhao et al. [26] reported that zeta-potential of alumina 
membrane decreased with an increase in $\mathrm{pH}$. This phenomenon could be explained that the treatment efficiency of turbidity decreased slightly, because the decrease of zeta potential of HC10 membrane resulted in a decrease of the electroviscous effect. However, in the previous result [23] for the hybrid process of the C005 and the pure PP beads, the treatment efficiency of turbidity was almost constantly above $98.7 \%$, independent of the $\mathrm{pH}$. This means that the $\mathrm{pH}$ could not affect treating the turbid matter for carbon fiber UF process with water backwashing.

Table 9. Water quality and treatment efficiency of turbidity in the hybrid process of 7-channel alumina MF (HC10) and PP beads for the effect of $\mathrm{pH}$ as compared with results of tubular carbon fiber UF (C005) membrane.

\begin{tabular}{|c|c|c|c|c|c|c|}
\hline \multirow{3}{*}{$\mathrm{pH}$} & \multicolumn{4}{|c|}{$\begin{array}{l}\text { Turbidity } \\
\text { (NTU) }\end{array}$} & \multicolumn{2}{|c|}{ Average Treatment Efficiency (\%) } \\
\hline & \multicolumn{2}{|c|}{ Feed Water } & \multicolumn{2}{|c|}{ Treated Water } & \multirow{2}{*}{$\begin{array}{l}7 \text { Channels } \\
\text { Alumina MF }\end{array}$} & \multirow{2}{*}{$\begin{array}{c}\text { Tubular Carbon } \\
\text { Fiber UF [23] }\end{array}$} \\
\hline & Range & Average & Range & Average & & \\
\hline 5 & $21.9-25.1$ & 23.4 & $0.297-0.379$ & 0.331 & 98.6 & 98.8 \\
\hline 6 & $22.4-24.5$ & 23.5 & $0.229-0.347$ & 0.321 & 98.6 & 98.8 \\
\hline 7 & $23.9-26.0$ & 25.0 & $0.387-0.439$ & 0.411 & 98.4 & 98.7 \\
\hline 8 & $23.4-25.7$ & 24.5 & $0.411-0.511$ & 0.471 & 98.1 & 99.0 \\
\hline 9 & $20.6-21.4$ & 20.9 & $0.399-0.487$ & 0.423 & 98.0 & 98.7 \\
\hline
\end{tabular}

As shown in Table 10, the treatment efficiency of DOM showed the highest value at a $\mathrm{pH}$ of 9. This means that DOM could be removed effectively at alkalic condition, because of the secondary layer on the membrane surface accumulated by the most severe membrane fouling. However, in the previous result [23] for the hybrid process of the C005 and the pure PP beads, the treatment efficiency of DOM was the highest at a $\mathrm{pH}$ of 5 . This means that DOM could be removed effectively at acid condition, because of repulsion force between the carbon fiber membrane and humic materials.

Table 10. Water quality and treatment efficiency of DOM ( $\mathrm{UV}_{254}$ absorbance) in the hybrid process of 7-channel alumina MF (HC10) and PP beads for the effect of $\mathrm{pH}$ as compared with results of tubular carbon fiber UF (C005) membrane.

\begin{tabular}{ccccccc}
\hline \multirow{2}{*}{$\mathbf{p H}$} & \multicolumn{3}{c}{$\mathbf{U V}_{\mathbf{2 5 4}}$ Absorbance $\mathbf{( c m}^{-\mathbf{1}} \mathbf{n}$} & \multicolumn{2}{c}{ Average Treatment Efficiency (\%) } \\
\cline { 2 - 5 } & \multicolumn{2}{c}{ Feed Water } & \multicolumn{2}{c}{ Treated Water } & \multirow{2}{*}{ 7 Channels } & Tubular Carbon \\
& Range & Average & Range & Average & Alumina MF & Fiber UF [23] \\
\cline { 2 - 5 } & $0.421-0.511$ & 0.493 & $0.211-0.264$ & 0.243 & 50.7 & 85.1 \\
5 & $0.478-0.513$ & 0.499 & $0.219-0.289$ & 0.252 & 49.4 & 81.6 \\
7 & $0.489-0.509$ & 0.497 & $0.239-0.269$ & 0.256 & 48.6 & 82.4 \\
8 & $0.458-0.527$ & 0.493 & $0.222-0.279$ & 0.253 & 48.7 & 82.3 \\
9 & $0.511-0.521$ & 0.516 & $0.213-0.271$ & 0.245 & 52.5 & 81.7 \\
\hline
\end{tabular}

\section{Conclusions}

In this study, the roles of humic acid, $\mathrm{PP}$ bead concentration, and $\mathrm{pH}$ were investigated on membrane fouling and treatment efficiency of turbid matter or DOM in the hybrid process of the multichannel alumina MF membrane and pure PP beads with periodic water backwashing. The results of $\mathrm{pH}$ effect were compared with those of the previous study $[22,23]$ in the hybrid process of the tubular carbon fiber UF and the same PP beads with water backwashing. In conclusion, the following results could be extracted from these investigations.

(1) DOM, such as HA, could drive membrane fouling more severely on the surface and inside the alumina membrane, with an increasing HA concentration in water; however, the thick fouling cake on the membrane could be removed by water backwashing at $10 \mathrm{mg} / \mathrm{L}$ of HA. DOM could affect 
the treatment of suspended particles, such as kaolin, in the hybrid process of the multichannel alumina MF and the pure PP beads; however, it could not affect the process of tubular carbon fiber UF membrane. DOM could be treated more effectively at high DOM condition in the hybrid water treatment process of seven-channel alumina MF and pure PP beads.

(2) The optimal PP beads concentration could be $5 \mathrm{~g} / \mathrm{L}$ to control the membrane fouling in this hybrid process of seven-channel alumina MF HC10 and PP beads. The tubid matters could be treated effectively, independent of PP beads concentration in this hybrid process. The optimal PP beads concentration was $5 \mathrm{~g} / \mathrm{L}$ to remove DOM in this hybrid process. The optimal PP beads concentration to reduce the turbid matter could be $30 \mathrm{~g} / \mathrm{L}$ in the hybrid process of C005 UF membrane.

(3) The reversible and irreversible membrane fouling, and concentration polarization could be inhibited at acid condition, because both the membrane and humic materials had a negative surface charge at acid conditions below $\mathrm{pH}$ 7. The turbid matter could be removed more effectively at an acidic $\mathrm{pH}$ condition in the hybrid process of the alumina HC10 MF membrane; however, $\mathrm{pH}$ could not affect treating the turbid matter for carbon fiber UF process. DOM could be removed effectively in alkalic condition, because of the secondary layer on the membrane surface accumulated by the most severe membrane fouling.

Author Contributions: Experiments, S.H. and Y.L.; writing—review and editing, J.Y.P. All authors have read and agreed to the published version of the manuscript.

Funding: This research received no external funding.

Conflicts of Interest: The authors declare no conflict of interest.

\section{References}

1. Meng, F.G.; Chae, S.R.; Drews, A.; Kraume, M.; Shin, H.S.; Yang, F. Recent advances in membrane bioreactors (MBRs): Membrane fouling and membrane material. Water Res. 2009, 43, 1489-1512. [CrossRef] [PubMed]

2. Liu, C.X.; Zhang, D.R.; He, Y.; Zhao, X.S.; Bai, R. Modification of membrane surface for anti-biofouling performance: Effect of anti-adhesion and anti-bacterial approaches. J. Membr. Sci. 2010, 346, 121-130. [CrossRef]

3. Yoon, Y.; Lueptow, R.M. Removal of organic contaminants by RO and NF membranes. J. Membr. Sci. 2005, 261, 76-86. [CrossRef] [PubMed]

4. Cui, X.; Choo, K.-H. Natural Organic Matter Removal and Fouling Control in Low-Pressure Membrane Filtration for Water Treatment. Environ. Eng. Res. 2014, 19, 1-8. [CrossRef]

5. Tian, J.; Wu, C.; Yu, H.; Gao, S.; Li, G.; Cui, F.; Qu, F. Applying ultraviolet/persulfate (UV/PS) pre-oxidation for controlling ultrafiltration membrane fouling by natural organic matter (NOM) in surface water. Water Res. 2018, 132, 190-199. [CrossRef]

6. Kusworo, T.D.; Utomo, D.P. Performance evaluation of double stage process using nano hybrid $\mathrm{PES} / \mathrm{SiO}_{2}-\mathrm{PES}$ membrane and PES/ZnO-PES membranes for oily waste water treatment to clean water. J. Environ. Chem. Eng. 2017, 5, 6077-6086. [CrossRef]

7. Szymański, K.; Morawski, A.W.; Mozia, S. Surface water treatment in hybrid systems coupling advanced oxidation processes and ultrafiltration using ceramic membrane. Desalin. Water Treat. 2017, 64, 302-306. [CrossRef]

8. Hofs, B.; Ogier, J.; Vries, D.; Beerendonk, E.F.; Cornelissen, E.R. Comparison of ceramic and polymeric membrane permeability and fouling using surface water. Sep. Purif. Technol. 2011, 79, 365-374. [CrossRef]

9. Liu, P.; Liu, J.; Wang, Z.; Jiao, Y.; Bie, A.; Xia, J. Application of inorganic ceramic membrane in treatment of emulsion wastewater. Oxid. Commun. 2016, 39, 2753-2757.

10. Zhang, H.; Zhong, Z.; Xing, W. Application of ceramic membranes in the treatment of oilfield-produced water: Effects of polyacrylamide and inorganic salts. Desalination 2013, 309, 84-90. [CrossRef]

11. Zhang, X.; Fan, L.; Roddick, F.A. Influence of the characteristics of soluble algal organic matter released from Microcystis aeruginosa on the fouling of a ceramic microfiltration membrane. J. Membr. Sci. 2013, 425, $23-29$. [CrossRef] 
12. Zhang, X.; Fan, L.; Roddick, F.A. Impact of the interaction between aquatic humic substances and algal organic matter on the fouling of a ceramic microfiltration membrane. Membranes 2018, 8, 7. [CrossRef] [PubMed]

13. Benito, A.; Penadés, A.; Lliberia, J.L.; Gonzalez-Olmos, R. Degradation pathways of aniline in aqueous solutions during electro-oxidation with BDD electrodes and $\mathrm{UV} / \mathrm{H}_{2} \mathrm{O}_{2}$ treatment. Chemosphere 2017, 166, 230-237. [CrossRef] [PubMed]

14. Khuzwayo, Z.; Chirwa, E.M.N. Analysis of catalyst photo-oxidation selectivity in the degradation of polyorganochlorinated pollutants in batch systems using $\mathrm{UV}$ and $\mathrm{UV} / \mathrm{TiO}_{2}$. S. Afr. J. Chem. Eng. 2017, 23, $17-25$.

15. Milelli, D.; Lemont, F.; Ruffel, L.; Barral, T.; Marchand, M. Thermo- and photo-oxidation reaction scheme in a treatment system using submerged plasma. Chem. Eng. J. 2017, 317, 1083-1091. [CrossRef]

16. Morgan, A.; Cocca, M.; Vega, K.; Fleischer, A.; Gupta, S.K.; Mehan, M.; Takacs, G.A. Vacuum UV photo-oxidation of poly(ethylene terephthalate). J. Adhes. Sci. Technol. 2017, 31, 2542-2554. [CrossRef]

17. Semitsoglou-Tsiapou, S.; Templeton, M.R.; Graham, N.J.D.; Hernández Leal, L.; Martijn, B.J.; Royce, A.; Kruithof, J.C. Low pressure $\mathrm{UV} / \mathrm{H}_{2} \mathrm{O}_{2}$ treatment for the degradation of the pesticides metaldehyde, clopyralid and mecoprop-Kinetics and reaction product formation. Water Res. 2016, 91, 285-294. [CrossRef]

18. Wu, X.H.; Su, P.B.; Liu, H.L.; Qi, L.L. Photocatalytic degradation of Rhodamine B under visible light with Nd-doped titanium dioxide films. J. Rare Earths 2009, 27, 739-743. [CrossRef]

19. Li, A.; Zhao, X.; Liu, H.; Qu, J. Characteristic transformation of humic acid during photoelectrocatalysis process and its subsequent disinfection byproduct formation potential. Water Res. 2011, 45, 6131-6140. [CrossRef]

20. Kim, N.Y.; Park, J.Y. Roles of polypropylene beads and photo-oxidation in hybrid water treatment process of alumina MF and photocatalyst-coated PP beads. Desalin. Water Treat. 2017, 58, 368-375. [CrossRef]

21. Park, J.Y.; Kim, S.; Bang, T. Effect of water back-flushing time and polypropylene beads in hybrid water treatment process of photocatalyst-coated PP beads and alumina microfiltration membrane. Membr. J. 2016, 26, 301-309. [CrossRef]

22. Park, Y.; Park, J.Y. Roles of adsorption and photo-oxidation in hybrid water treatment process of tubular carbon fiber ultrafiltration and PP beads with UV irradiation and water back-flushing. Desalin. Water Treat. 2017, 61, 20-28. [CrossRef]

23. Song, S.; Park, Y.; Park, J.Y. Roles of polypropylene beads and $\mathrm{pH}$ in hybrid water treatment of carbon fiber membrane and PP beads with water back-flushing. Membr. Water Treat. 2019, 10, 155-163.

24. Gao, S.C.; Park, J.Y. Advanced water treatment of high turbidity source by hybrid process of ceramic ultrafiltration and photocatalyst: 1 . Effect of photocatalyst and water-back-flushing condition. Membr. J. 2011, 21, 127-140.

25. Zhao, Y.; Zhou, S.; Li, M. Humic acid removal and easy-cleanability using temperature responsive $\mathrm{ZrO}_{2}$ tubular membranes grafted with poly(N-isopropylacrylamide) brush chains. Water Res. 2013, 47, 2375-2386. [CrossRef]

26. Zhao, Y.; Xing, W.; Xu, N.; Wong, F.-S. Effects of inorganic salt on ceramic membrane MF of titanium dioxide suspension. J. Membr. Sci. 2005, 254, 81-88. [CrossRef]

(C) 2019 by the authors. Licensee MDPI, Basel, Switzerland. This article is an open access article distributed under the terms and conditions of the Creative Commons Attribution (CC BY) license (http://creativecommons.org/licenses/by/4.0/). 